\title{
Wybrane czynniki warunkujące kompetencje szkolne z perspektywy wspólczesnych neuronauk i nauk pedagogicznych
}

\section{Summary \\ SELECTED FACTORS AFFECTING SCHOOL COMPETENCES FROM THE PERSPECTIVE OF NEUROSCIENCE AND PEDAGOGY}

There are several sources that determine school abilities: endogenous factors, i.e. abilities, intelligence, personality, internal motivation, and exogenous factors, such as environment and external motivation. The causes of school failures are found most often in the level of fluid or crystallised intelligence. In particular in the fluid intelligence, which is genetically conditioned.

The type of personality also affects the achievement in learning, as well as the pleasure derived from it. The motives (for which students take action) can also have an impact on achievements - school abilities. There are two types of motivation: internal and external. The internal, exogenous motivation has an extremely strong positive impact and it should be stimulated by mentors - teachers. Furthermore, there are several types of general abilities that also affect school competences. Abilities should be noticed and developed during school education. Undoubtedly, the educational system should develop creativity and support the development of all individual characteristics, providing opportunity for self-fulfilment.

Key words: school abilities, neuropedagogy, neurodidactics, intelligence, personality, school, motivation, abilities 


\section{Wprowadzenie}

Wieloletnie analizy pedagogiczne wskazują, iż można wyróżnić kilka głównych źródeł, warunkujących zróżnicowanie w osiągnięciach uczniów - kompetencjach szkolnych, które opisuje się często jako zespół umiejętności uczenia się, korzystania z wiedzy, a także motywowania się, co ma bezpośredni wpływ na funkcjonowanie w realiach szkolnych.

Zagadnienie to jest niezwykle nurtujące, gdyż wpływ na kompetencje szkolne mają czynniki zarówno endogenne (sami uczniowie - zdolności, inteligencja, osobowość, motywacja wewnętrzna), jak i egzogenne (środowisko, motywacja zewnętrzna). Dyskusja na temat czynników warunkujących kompetencje szkolne $\mathrm{z}$ pewnością jest potrzebna i będzie prowadzona permanentnie, dodatkowo uwzględniając obecnie m.in. sposoby finansowania oświaty, liczebność klas itd. Dyskusje o reformach edukacyjnych w większości krajów opierają się na analizie wpływu głównie środowiska rodzinnego, struktury szkoły, sposobu finansowania czy zaangażowania opiekunów w prowadzenie placówek, jednak zdaniem Johna Hattie rozwiązań szuka się w niewłaściwym miejscu. Jak uważa cytowany autor wysiłki należy skierować na wzmocnienie najbardziej efektywnego czynnika, jakim jest jakość pracy nauczyciela (Hattie 2003). Oznacza to, że w dobie dzisiejszej wiedzy o mózgu, nauczyciel musi stać się mentorem, który pozwoli na rozwój młodych osób (uczniów), wspierając proces nauczania-uczenia się, zgodnie z neurobiologicznymi podstawami przyswajania wiedzy i rozwoju mózgu dziecka. Fortunnie, powtarzając za Taraszkiewicz (2014) już od kilkunastu lat obserwuje się dyskusje, których przesłanie można określić frazą: „o edukacji uzasadnionej neurobiologicznie”. Dostrzega się potrzebę wyposażenia nauczycieli w aktualną wiedzę na temat funkcjonowania mózgu - rozwijając tym samym nową subdyscyplinę neuropedagogiki/ neurodydaktyki.

Bez wątpienia wiedza stricte neurobiologiczna na temat czynników warunkujących kompetencje szkolne musi być rozwijana ciągle, a nauczyciele powinni otworzyć się na proces samokształcenia-samodoskonalenia swojego warsztatu, zgodnie z najnowszą wiedzą.

Celem tej pracy jest ukazanie zarysu podstaw neuronaukowych warunkujących zróżnicowanie uczniów pod względem kompetencji szkolnych (osiągnięć). 


\section{Czynniki warunkujące kompetencje szkolne}

\section{Inteligencja a kompetencje szkolne}

Zagadnienie struktury zdolności intelektualnych stanowi przedmiot zainteresowań wielu naukowców. Już w starożytności doceniano znaczenie rozumu w osiąganiu sukcesu jednostki w różnych wymiarach działalności ludzkiej, a co za tym idzie wysokiej pozycji społecznej. Zdolności intelektualne stanowią również bazę w konstytuowaniu określonych zasad aksjologicznych, które powinny być rudymentarnym źródłem postępowania jednostki - humanizm i humanitaryzm. Stworzenie pojęcia inteligencji przypisuje się Cyceronowi, według którego: „inteligencja to zdolności intelektualne człowieka, w odróżnieniu od jego woli i emocji” (Sękowski, Bilyakovska 2011). W późniejszym czasie wielu naukowców tworzyło swoje definicje inteligencji. Francis Galton (1865) postulował, iż istnieje zdolność ogólna, nazywana inteligencją, jako coś przeciwnego do zdolności specjalnych. W latach 30. XX w. niemiecki uczony William Stern zaproponował, iż inteligencja to ogólna, wrodzona zdolność adaptacji do nowych zadań i warunków (Czelakowska 2007).

W 1946 r. brytyjski naukowiec Charles Spearman natomiast wyodrębnił czynnik ogólny g (general factor) - obiektywizujący się we wszystkich zachowaniach człowieka; podstawę jego stanowi proces rozumowania i wnioskowania - jako wartość statystyczna najsilniej korelująca z wykonaniem zadań intelektualnych - czyli właściwą inteligencją - oraz czynnik odpowiedzialny za specyficzne zdolności człowieka (Spearman 1946). Z kolei Daniel Goleman stwierdził, iż istnieją dwa typy inteligencji: intelektualna oraz emocjonalna (1999). Stanley Greenspan zaś uważa, iż inteligencja człowieka rozwija się dzięki procesom tworzenia i opracowywania emocjonalnych doświadczeń (Greenspan, Benderly 2000). Inny badacz Lewis Terman, określił inteligencję jako zdolność do myślenia abstrakcyjnego. Podobnie David Wechsler, który uważał, iż są to zdolności rozumienia świata i zasoby pozwalające stawić czoła jego wyzwaniom (Terman, Merrill 1937; Wechsler 1949). Robert Sternberg zdefiniował inteligencję jako zdolność jednostki do zachowania adaptacyjnego, skierowanego na cel (Hamer, Copeland 1998). Trafną, jak się wydaje, z punktu widzenia neurodydaktyki definicję inteligencji zaprezentowała Linda Gottfredson: „inteligencja to bardzo ogólna zdolność umysłowa, która obejmuje m.in. umiejętność rozumowania, planowania, rozwiązywania problemów, myślenia abstrakcyjnego, rozumienia 
złożonych kwestii, szybkiego uczenia się oraz uczenia się na podstawie osobistego doświadczenia” (Gottfredson 1997).

Niezwykle ciekawe jest pojęcie dziedziczności inteligencji - w czasach nowożytnych badania nad dziedzicznością inteligencji opublikował Galton w pracy Hereditary genius (1869). Autor był przekonany, że „geniusz” jest nabywany w drodze dziedziczenia i próbował ten pogląd udowodnić w szeroko zakrojonych badaniach statystycznych. Badając zjawisko dziedziczności uzdolnień, Galton zauważył i opisał zjawisko tzw. regresji do średniej. Polega ono na tym, że potomstwo osobników wysoce uzdolnionych jest przeciętnie mniej uzdolnione od swoich rodziców. Cecha jak gdyby „cofa się” w wyniku dziedziczenia, co uznano za przejaw degeneracji geniuszu w wyniku przekazywania go z pokolenia na pokolenie. Naukowiec nie zauważył jednak zjawiska odwrotnego, czyli wzrostu przeciętnego poziomu uzdolnień potomstwa osób mniej zdolnych w stosunku do pokolenia rodzicielskiego (Galton 1892). Z drugiej strony powołując się na tzw. Efekt Flynna (Flynn 1984) stwierdzić można, iż IQ (iloraz inteligencji) wzrasta $z$ generacji na generację. Co to oznacza? IQ w danej populacji powinno wynosić 100 - średnia. Gdybyśmy jednak stosowali współczesne normy IQ do ilorazu przodków, albo gdybyśmy porównali IQ dwadzieścia lat wstecz, to zauważylibyśmy, że właściwie we wszystkich krajach IQ wzrasta $\mathrm{z}$ pokolenia na pokolenie.

Oczywiście poprzez to, iż standardy mierzenia IQ zmieniają się z czasem, obecnie niekoniecznie (niebezrefleksyjnie) twierdzimy, że ogólny trend inteligencji wyznaczają, czy to prace Galtona, czy Flynna. Z całą pewnością jednak te badania pokazują, iż umysły zmieniają się z czasem (co w konsekwencji warunkuje również zmianę podejścia pedagogicznego).

Obecnie postuluje się, że silnie związaną strukturą mózgową z inteligencją płynną (zdeterminowana przez czynnik biologiczny - wrodzona, rozwijana do momentu zakończenia rozwoju człowieka) jest kora przedczołowa. Co ciekawe, zauważono ponadto, iż osoby z urazami kory przedczołowej w testach matryc progresywnych Ravena (intelekt skrystalizowany - związany z umiejętnościami i doświadczeniem życiowym) osiągają wyniki na poziomie upośledzenia umysłowego (Waltz $\mathrm{i}$ in. 1999; Blair $\mathrm{i}$ in. 2005). W badaniach rozwoju kory przedczołowej wykazano, iż rozwój tej części kory jest przedłużony i pojawia się obszar, w którym synaptogeneza (powstawanie nowych synaps) jest zależna od synaptycznej stabilizacji, o której wiadomo, że stanowi podstawę uczenia się, procesów pamięciowych i funkcji wykonawczych (Benes 2001; Semendeferi $i$ in. 2002; Goldman-Rakic $i$ in. 1997), zatem może być silnie skorelowana $\mathrm{z}$ inteligencją. 
O znaczącym wpływie genotypu na inteligencję przemawiają nowe badania prowadzone na bliźniętach. Bouchard i inni (1990) wskazują na dziedziczność inteligencji na poziomie $70 \%$. Obecnie wiadomo, iż inteligencja nie jest cechą determinowaną wyłącznie przez jeden gen. Podkreśla się, iż jest ona cechą wielogenową. W eksperymentalnych pracach Plomina i in. (2004) zidentyfikowano tzw. markery genetyczne, ściśle powiązane $\mathrm{z}$ niską oraz wysoką wartością IQ. Uważa się obecnie, że genów wpływających na poziom intelektu należy upatrywać się a priori w grupie genów, których produkty białkowe związane są z rozwojem układu nerwowego (Plomin $i$ in. 1995). Luciano $i$ in. (2006) potwierdzili dodatni związek między markerami zlokalizowanymi na długim ramieniu chromosomu 2 (2q) oraz krótkim ramieniu chromosomu 6 (6p) a inteligencją. Geny: GAD1, NOSTRIN, KCNH7, TBR1, DLX1 oraz DLX2 zaangażowane są m.in. $w$ regulację przewodzenia nerwowego, uwalniania neutrotransmitterów oraz funkcje określonych struktur OUN, takich jak kora mózgowa (Addington i in. 2005; Hyde $\mathrm{i}$ in. 2011; Leverenz $\mathrm{i}$ in. 2009; Luciano $\mathrm{i}$ in. 2006). Gen DTNBP1, kodujący białko dysbindynę wydzielany jest natomiast głównie w OUN (Weickert i in. 2004), a także jako kompleks alfa-, beta-dystrobrewinowy w obrębie układu mięśniowego. Jak wskazują dane nieprawidłowe tworzenie kompleksów przez disbindynę, może być przyczyną obniżenia sprawności intelektualnej u niektórych chorych na tę dystrofię mięśniową (Benson i in. 2001; Blake i in. 1998). Dysbindyna bierze udział w wychwycie zwrotnym kwasu glutaminowego (L-glutaminianu), wpływa na sprawność synaps, oddziałuje modulująco na receptory NMDA- i GABA-ergiczne (Zhang $i$ in. 2010; Schwab i in. 2003; Talbot $\mathrm{i}$ in. 2004). Zaobserwowanie obniżonego poziomu disbindyny wśród chorych na schizofrenię, u których zostały zaburzone funkcje poznawcze, było przesłanką do oceny wpływu polimorfizmów genu DTNBP1 na poziom inteligencji wśród osób zdrowych. Jeden z analizowanych przez Burdicka i wsp. haplotypów (CTCTAC) genu DTNBP1, miał ścisły związek z wynikami testu na inteligencję, uzyskiwanymi przez osoby badane. Jego obecność w genomie objawiała się obniżonym stężeniem dysbindyny. Nosiciele tej zmiany, cechowali się niższym poziomem inteligencji (Burdick i in. 2006). Wiele badań, których celem było określenie genetycznego podłoża inteligencji, dotyczyło neuroprzekaźników. Jednymi z genów kandydujących były geny układu dopaminergicznego, ze względu m.in. na upośledzenie funkcji kognitywnych u chorych na drżączkę poraźną, czyli inaczej chorobę Parkinsona, wynikające z obniżonego stężenia dopaminy, a także zaangażowanie dopaminy m.in. w myślenie abstrakcyjne i pamięć roboczą (Cooper, Sagar 1993; Leverenz i in. 2009; Soderqvist i in. 2012). Badania 
skupiły się przede wszystkim na polimorfizmach genów receptorów dopaminergicznych D2 oraz D4, genu metylotransferazy katecholowej (COMT), genu SLC6A3 kodującego transporter dopaminy - DAT oraz na skutkach ich wzajemnego oddziaływania. Bolton i in. (2010) w grupie 2091 kobiet i mężczyzn dostrzegli korelacje między obniżonym poziomem inteligencji a aberracjami w obrębie genu DRD2 - kodującego receptory D2. W przypadku polimorfizmów genu DRD4 (kodującego receptory D4) zaobserwowano obniżone wyniki w testach oceniających pamięć roboczą (Altink i in. 2012). W niezwykle ciekawej pracy Mill i in. (2006) badali wpływ zmiennej liczby powtórzeń tandemowych genów DRD4 oraz SLC6A3 na poziom inteligencji wśród dzieci z ADHD oraz dzieci zdrowych, pochodzących z populacji brytyjskiej oraz nowozelandzkiej. Wyniki badań obu populacji były podobne. Dzieci z ADHD miały niższe IQ niż dzieci zdrowe. W badaniach w grupie z ADHD, najniższe IQ miały dzieci, które były nosicielami zwiększonej liczby powtórzeń tandemowych, zarówno w genie DRD4 jak i SLC6A3. Najwyższe IQ miały dzieci, u których nie stwierdzono zwiększonej liczby sekwencji tandemowych w żadnym z badanych genów.

Jako potencjalne czynniki mogące wpływać na poziom inteligencji pod uwagę wzięto także enzymy OUN, a wśród nich katecholo-O-metylotransferazę (COMT). COMT jest enzymem inaktywującym aminy katecholowe, w tym dopaminę (Dickinson, Elevag 2009). Polimorfizm czynnościowy g.27009G >A (c.472G >A, p.Val158Met) katecholo-O-metylotransferazy prowadzi do substytucji waliny przez metioninę. Enzym zawierający metioninę jest 3-4 razy mniej aktywny niż enzym zawierający walinę, co powoduje mniejsze nasilenie inaktywacji i dłuższy okres półtrwania amin katecholowych (Lachman i in. 1996). Badania nad wpływem polimorfizmu COMT na inteligencję przyniosły zróżnicowane wyniki. Bolton i in. (2010) w badaniach w grupie zdrowych kobiet i mężczyzn nie stwierdzili by ta substytucja wpływała na poziom inteligencji. Odmienne wyniki przyniosła meta-analiza związku aktywności COMT z inteligencją. Analizie poddano wyniki 46 badań przeprowadzonych w latach 2001-2007 w niezależnych ośrodkach, w których określano wpływ polimorfizmu g.27009G >A genu COMT na IQ. Badaniom poddano osoby zdrowe, a także chorych na schizofrenię oraz chorobę afektywną dwubiegunową. Badani byli zróżnicowani pod względem płci, wieku i pochodzenia. Wyniki analizy wskazały na pozytywny związek między poziomem inteligencji $\mathrm{i}$ obecnością metioniny $\mathrm{w}$ obu allelach genu COMT, a więc i postacią enzymu o obniżonej aktywności. Nie wykazano natomiast związku między inteligencją a płcią, wiekiem czy pochodzeniem (Barnett i in. 2008). Obecność metioniny w strukturze białka miała także korzystny wpływ 
na wyniki testów określających pamięć roboczą, a także pamięć epizodyczną (Egan $\mathrm{i}$ in. 2001). Nie wykazano natomiast związku z pamięcią semantyczną, a także uwagą, funkcjami wykonawczymi i szybkością przetwarzania informacji (De Frias i in. 2004; O'Hara i in. 2006).

Od bardzo dawna staramy się znaleźć odpowiedź na pytanie, dlaczego jedni ludzie lepiej od innych radzą sobie w procesie uczenia się. Najczęściej przyczyn sukcesów lub niepowodzeń doszukujemy się w poziomie inteligencji płynnej czy skrystalizowanej, bądź też w cechach osobowości. Termin kompetencje szkolne proponuje się rozumieć jako zespół umiejętności uczenia się, korzystania z wiedzy oraz motywowania się, co ma bezpośredni wpływ na funkcjonowanie. O poziomie kompetencji szkolnych wnioskuje się na podstawie tzw. osiągnięć, a więc np. ocen z egzaminów lub średniej ocen. Zatem na poziom kompetencji szkolnych ogromny wpływ będzie miała inteligencja rozumiana jako umysłowa zdolność do emitowania zachowań dostosowanych do kontekstu, obejmująca radzenie sobie z sytuacjami nowymi (Sternberg 1985). Sprawne wykonywanie zadań szkolnych jest także funkcją nabywania i wykorzystywania wiedzy, rozumianą jako selektywne kodowanie, czyli odsiewanie informacji pobieranych $\mathrm{z}$ zewnątrz ze względu na ich ocenianą istotność dla zadania, selektywne kombinowanie, a więc zestawianie wcześniej przesianych informacji w większe, sensowne całości oraz selektywne porównywanie, czyli odnoszenie informacji pobranych $\mathrm{z}$ zewnątrz do informacji nabytych $\mathrm{w}$ przeszłości (Davidson, Sternberg 1983). Wpływ intelektu na poziom funkcjonowania szkolnego jest dobrze potwierdzony eksperymentalnie (Brown, DeLoache 1978; Goff, Accerman 1992).

Maciej Karwowski (2013) zauważył, iż związek między osiągnięciami szkolnymi a inteligencją uzależniony jest zarówno od rodzaju inteligencji, jak i od sposobu zdobywania osiągnięć szkolnych. Najsilniej z osiągnięciami szkolnymi związana jest inteligencja skrystalizowana, siła związku inteligencji płynnej z osiągnięciami jest słabsza. Jak wskazuje Age Diseth i in. (2010) w przypadku średniej ocen związek $z$ inteligencją skrystalizowaną waha się między $r=0,23$. Inteligencja koreluje ze średnią ocen szkolnych w słabszym stopniu (Konarzewski 1996) - na poziomie $r=0,15$ (Gralewski, Karwowski 2012). Polskie badanie przeprowadzone przez Centralną Komisję Egzaminacyjną (CKE) potwierdza istnienie istotnej korelacji między inteligencją uczniów a uzyskiwanymi przez nich wynikami egzaminów zewnętrznych (Wieczorkowska, Sarkiewicz 2007). Podczas Warsaw Study II w 1995 r. skontaktowano się ponownie z wybraną grupą osób o wysokim oraz niskim IQ, zdiagnozowanym w dzieciństwie. Niemal 90\% 
osób o niskim ilorazie inteligencji skończyło edukację na szkole podstawowej bądź zawodowej, podobna liczba osób o wysokim IQ zdiagnozowanym w wieku 13 lat uzyskało wykształcenie wyższe, niektórzy badani uzyskali również stopień doktora (Firkowska-Mankiewicz 2002).

\section{Osobowość a kompetencje szkolne}

Osobowość człowieka traktuje się jako zespół cech. Według definicji są to nawykowe reakcje, które na wyższym poziomie organizacji w pewnych grupach tworzą wzajemne powiązania tj. typy, czyli trzy wymiary.

Hans Eysenck $(1985 ; 1995)$ analizował trzy główne czynniki osobowości (Wielka Trójka):

- ekstra-introwersję, czyli poziom kierowania swoich działań ku otoczeniu. Wyraża ona kontinuum od skrajnej introwersji do ekstrawersji. Introwertyk i ekstrawertyk różnią się w zakresie reagowania: u ekstrawertyka występuje przewaga procesów pobudzenia nad hamowaniem (układ sympatyczny), a u introwertyka przewaga procesów hamowania nad pobudzeniem (układ parasympatyczny);

- neurotyczność, rozumianą jako miarę stabilności emocjonalnej człowieka. Neurotyzm określa osoby labilne uczuciowo, o niskim progu wrażliwości a wysokiej reaktywności, skłonne do silnego i trwałego reagowania na klasę bodźców działających na układ sympatyczny (pobudzający i wzmacniający reakcje); Neurotyzm wiąże się ponadto $\mathrm{z}$ wyższym bazalnym poziomem kortyzolu (hormonu stresu), ale z obniżonym fazowym wzrostem tego hormonu w reakcji na specyficzne czynniki stresogenne (Netter 2004). Postuluje się ponadto inny bilans między poziomem serotoniny i noradrenaliny w niektórych strukturach mózgowia (Gray, McNaughton 2000; Cools i in. 2005; Hennig 2004), aniżeli standardowo w innych typach osobowości;

- psychotyczność, którą charakteryzują m.in. brak empatii, agresja, impulsywność czy egocentryzm (Eysenck 1995). Psychotyzm jest również definiowany jako „twardość myślenia”. Jak opisuje Pospiszyl (1992) to taka osoba „często bawi się kosztem innych ludzi, specjalizując się w wyprowadzaniu innych z równowagi".

Natomiast w ramach modelu pięciu wymiarów osobowości, wyróżnia się tzw. Wielką Piątkę. Taksonomia pięciu podstawowych cech osobowości wyrasta $\mathrm{z}$ dwóch różnych tradycji badawczych: nurtu leksykalnego oraz podejścia kwestionariuszowego. W nurcie leksykalnym model pięcioczynnikowy został 
odkryty i wstępnie zweryfikowany (Fiske 1949; Norman 1963; Goldberg 1981, 1990; Tupes, Christal 1992). W nurcie psychometrycznym model osadzono w kontekście teoretycznym oraz rozwinięto koncepcyjnie i empirycznie (Costa, McCrae 1992; McCrae, Costa 1999, 2005). Autorzy teorii sprowadzają ogół zmiennych osobowości jak zostało wspomniane do pięciu głównych czynników: neurotyczności; ekstrawersji; otwartości na doświadczenie, rozumianej jako intelektualna ciekawość człowieka; sumienności oraz ugodowości (Costa, McCrae 1997). Model ten jest jednak obecnie szeroko dyskutowany oraz krytykowany (Strus, Cieciuch 2014). W ostatnim czasie powstawały także modele powiększające liczbę wymiarów, np. do sześciu (Becker 1999), a nawet siedmiu czy więcej (Saucier 2008; De Raad 2009).

Obecnie najpoważniejszą alternatywą dla Wielkiej Piątki jest sześcioczynnikowy model HEXACO, zaproponowany na początku XXI w. (Ashton i in. 2000; Ashton, Lee 2001). Model ten zawiera w sobie: uczciwość-skromność (honesty-humility), emocjonalność (emotionality), ekstrawersję (extraversion), ugodowość (agreeableness), sumienność (conscientiousness), otwartość na doświadczenia (opennes to experience). Model ten daje większe możliwości analizy dzięki uwzględnieniu szóstego czynnika uczciwość-skromność (honesty-humility) (Chirumbolo, Leone 2010). Oczywiście, osobowość człowieka pomimo iż badania nad nią wywodzą się z klasycznej psychologii podejmowana jest również jako zagadnienie $\mathrm{w}$ innych dziedzinach nauki. Wyróżnia się cztery tzw. wzory osobowości (typ A, typ B, typ C oraz typ D). Taksonomia ta określa i wskazuje, że pewne cechy osobowości wiążą się ze specyficzną podatnością na czynniki zewnętrzne. Tak na przykład typ A (nacechowany agresją i wrogością) sprzyja chorobie niedokrwiennej serca, czy typ C (nacechowany represją emocjonalną, poczuciem bezradności $w$ sytuacjach stresowych) związany jest ze skłonnością do chorób nowotworowych (Friedman, Booth-Kewley. 1987; Izdebski 2007).

Już od dawna psychologowie, badając zachowania społeczne człowieka, zauważyli, że pewne osoby funkcjonują w środowisku społecznym o wiele bardziej efektywnie niż inne. Zagadnienie występowania różnic indywidualnych w zakresie funkcjonowania interpersonalnego jest o tyle istotne, że wysokie umiejętności społeczne pozwalają na trafne przewidywanie sukcesów jednostki nie tylko w sytuacjach o charakterze typowo społecznym, ale także w sytuacjach zadaniowych, wymagających często $\mathrm{z}$ założenia umiejętności głównie intelektualnych (np. sukcesy zawodowe czy akademickie). Uważa się obecnie, że natura i uwarunkowania „inteligencji społecznej” w dużym stopniu zależą od cech osobowościowych. 
Wydaje się, że osobowość może wpływać modyfikująco na wszystkie poziomy procesu przetwarzania informacji, a tym samym na proces i wynik uczenia się (Chamorro-Premuzic, Furnham 2008). Ciekawych danych dostarczają badania eksplorujące tzw. szarą strefę między osobowością a inteligencją (Mayer i in. 1989). Zgodnie z tym poglądem, cechy należące do tej strefy są ciągle postrzegane jako cechy osobowościowe, ale jednocześnie są odpowiedzialne za wynik aktywności intelektualnej. Do cech z pogranicza inteligencji i osobowości zalicza się m.in. absorpcję, opisującą gotowość na wzbudzenie głębokiego doświadczenia wewnętrznego (Tellegen, Atkinson 1974; Roche, McConkey 1990), otwartość na doświadczenie emocjonalne i poznawcze zachodzące w różnorodnych sytuacjach (Roche, McConcey 1990), zaangażowanie w wewnętrzną aktywność przy całkowicie zablokowanej stymulacji, płynącej ze świata zewnętrznego (Tellegen, Atkinson 1974).

Mayer i współpracownicy (1989) wskazują na wyróżnienie pojęć takich jak: przyjemność intelektualna i apatia intelektualna. Apatię intelektualną definiują jako znaczne obniżenie zainteresowań poznawczych i aktywności intelektualnej, niemoc, jakiej doświadcza się w obliczu problemów. Towarzyszy temu przygnębienie, poczucie rezygnacji, brak wiary we własne siły (niska samoocena) $i$ indyferentyzm dotykający sferę poznawania. Apatia intelektualna jest poczuciem, że myślenie jest trudne, mało pociągające i nudne. Osoba charakteryzująca się apatią intelektualną będzie odczuwała brak motywacji do podejmowania zadań intelektualnych, które uważa za nieatrakcyjne. Ostatnia z cech opisywanych przez Mayera i współpracowników - przyjemność intelektualna - oznacza pozytywne odczucia spowodowane wewnętrzną gratyfikacją towarzyszącą funkcjonowaniu intelektualnemu. Jest ona $\mathrm{z}$ jednej strony powiązana $\mathrm{z}$ radością rozwiązania jakiegoś problemu, z drugiej zaś oznacza przyjemność, jaką się czerpie z kontaktu intelektualnego z problemem, z możliwości przedstawienia swoich własnych rozwiązań, z przedyskutowania kwestii intelektualnych oraz $\mathrm{z}$ odegrania pewnej roli w sporze. Badacze ci sugerują, że cechy te są bardzo ściśle powiązane z poziomem wykonywania zadań intelektualnych, gdyż wydają się zawierać znaczny komponent poznawczy (Mayer i in. 1989; Kossowska, Nęcka 1994).

Z niskim poziomem osiągnięć $w$ nauce łączy się często osobowość psychotyczną (Eysenck 1985). Ponadto jak wskazują Furnham i Medhurst (1995) wysoki poziom psychotyczności wiąże się z mniejszymi zdolnościami lingwistycznymi (Heaven i in. 2002). Co fascynujące, istnieją badania wskazujące, iż uczniowie o niższym stopniu osiągnięć szkolnych byli mniej uspołecznieni i rzadziej uznawali autorytetów rodziców i nauczycieli (Gowan 1955). Współczesne 
rezultaty badań dowodzą, że wraz ze wzrostem osiągnięć szkolnych wzrasta poziom uspołecznienia i akceptacji ze strony rówieśników (Oberle, Schonert-Reich 2013). Niektórzy badacze dostrzegają ponadto związki między psychotycznością a cechami związanymi z kreatywnością (Aguilar-Alonso 1996; Merten, Fischer 1999; Woody, Clardige 1977). Wyróżnia się tutaj powiązania z fluencją słowną (Kline, Cooper 1986).

Do ciekawych wniosków dojdziemy wertując wyniki metaanalizy Arthura Poropata. Wynika z niej, że związek osiągnięć szkolnych z sumiennością cechuje się umiarkowanym nasileniem. Sumienność pojmowana przez wielu badaczy jako pozapoznawczy odpowiednik czynnika g wyjaśnia część wariancji osiągnięć szkolnych (De Fruyt, Mervielde 1996). Współgra to z faktem współistnienia wysokiego poziomu sumienności z wysokim poziomem motywacji samoistnej (Furnham, Medhurst 1995) oraz z niezawodnością, obowiązkowością, samokontrolą i fachowością (Costa, McCrae 1985), czy niską absencją na zajęciach i pozytywnym zachowaniem w klasie (Furnham i in. 2003). Podkreślić należy jednak, iż sumienność może odgrywać rolę kompensacyjną wśród uczniów o niższym ilorazie inteligencji, jako cecha negatywnie związana $z$ inteligencją płynną i jednocześnie pozytywnie skorelowana $\mathrm{z}$ wynikami egzaminów (Chamorro-Premuzic, Furnham 2008). Relacja między osiągnięciami szkolnymi a otwartością na doświadczenie, choć pozytywna, jest słaba, jak wskazuje Poropat (2009). Otwartość jednak może stać się mediatorem między poziomem inteligencji a osiągnięciami szkolnymi - uczniowie o wysokim ilorazie (IQ) osiągają lepsze wyniki szkolne, ponieważ są bardziej otwarci na nowe doświadczenia (Chamorro-Premuzic, Furnham 2008). Jak wskazuje Feist (1998) ugodowość jest związana w bardzo słabym stopniu z kreatywnością. Co ciekawe, obserwacje są zwykle ujemne (Furnham i in. 2011; Walker, Jackson 2014) bądź nieistotne (Hughes $\mathrm{i}$ in. 2013). Znikome związki obserwuje się także między osiągnięciami szkolnymi a stabilnością emocjonalną (Poropat 2009), w przypadku neurotyczności korelacja ma kierunek negatywny (Laidra i in. 2007). Również związek osiągnięć szkolnych z ekstrawersją jest znikomy (Hendriks i in. 2011; Poropat 2009) i występuje jedynie w pojedynczych klasach szkolnych (Laidra $\mathrm{i}$ in. 2007). Jednak już w przypadku kreatywności obserwuje się pozytywne korelacje (ekstrawersja i kreatywność) o średnim nasileniu (Hoseinifar i in. 2011).

Colin DeYoung i Jacob Hirsh (2010) relatywnie niedawno porównywali budowę mózgu ludzi o różnych typach osobowości (Wielka Piątka). Autorzy badania zaobserwowali wiele drobnych różnic anatomicznych, dochodząc przy tym 
do wniosku, iż ludzie z natury otwarci i ekstrawertyczni są zdecydowanie bardziej kreatywni i otwarci na odbiór nowości, piękna. Zauważono, iż osoby z tych grup cechują się inną (większą) aktywnością mózgowego układu nagrody, czyli szlaku dopaminergicznego łączącego pole brzuszne nakrywki (VTA) z jądrem półleżącym (NA). Natura obdarowała tych ludzi specyficzną wersją genów kodujących enzymy: monoaminooksydazę (MAO) oraz metylotransferazę katecholową (COMT), które odpowiadają za regulację poziomu dopaminy (DA) w OUN.

Odnotowano ponadto, że ekstrawertycy mają dodatkowo powiększoną tę część kory mózgowej, którą obrazowo można określić, powtarzając za Vetulanim „ośrodkiem odbioru piękna” w mózgu. Wydaje się zatem, że osoby z natury otwarte oraz ekstrawertycy doznają w kontakcie z pięknem dużo więcej przyjemności niż osoby o innych uwarunkowaniach osobowościowych. Nie istnieją badania przenoszące te wyniki do sfery neuropedagogicznej, tzn. czy ta grupa osób odczuwa również większą przyjemność z udziału w procesie uczenia się. Jednak można przypuszczać, iż potencjalnie możliwy jest taki związek.

\section{Motywacja a kompetencje szkolne}

Motywy, dla których podejmujemy różnorodne działania mogą mieć wpływ na kompetencje szkolne. W różnorakich koncepcjach zdolności (Amabile 1983; Renzulli 1986) jednym z komponentów jest czynnik motywacyjny, który wskazuje na gotowość człowieka do działania. Motywację rozdzielić można na zewnętrzną oraz wewnętrzną. Można ją też rozróżnić ze względu na powód zaangażowania w zadanie (Amabile 1985). Obok poziomu inteligencji i właściwości osobowościowych obserwuje się istotne związki między osiągnięciami szkolnymi i motywacją (Parkerson i in. 1984; Reynolds, Walberg 1991).

Jak wskazuje Adelle Gottfried (1985) uczniowie o motywacji samoistnej, a zatem powodowani wewnętrznym bodźcem są chętni do poszukiwania i poszerzania swojej wiedzy i umiejętności, charakteryzują się wzmożonym wysiłkiem, wytrwałością i zdolnością do emocjonalnego przystosowania się w obliczu trudności. Co ciekawe, postrzegają oni porażki jako konstruktywne narzędzie, które pozwala poszerzać wiedzę, uczyć się nowych zachowań i strategii (Pintrich, Zusho 2002). Na drugim biegunie uczniowie o motywacji zewnętrznej czerpią satysfakcję $\mathrm{z}$ takich form aktywności, które przynoszą im nagrodę, lepszą ocenę, uznanie w oczach mentora, czy rówieśników (Harter 1981). 
Wydaje się, iż motywacja wewnętrzna stanowi silniejszy i bardziej pozytywny - „zdrowy” bodziec do nauki niż czynniki zewnętrzne. John Dewey wykazywał, iż „najistotniejszą postawą, jaką można wykształcić podczas procesu nauczania, jest chęć do nauki” (1938/1963).

Czynniki warunkujące motywację egzogenną (zewnętrzną) są mało stabilne, zatem uczeń osiągać będzie wysokie wyniki tak długo, dopóty te czynniki będą oddziaływać.

Karwowski (2006) wskazuje, iż motywatory egzogenne mogą mieć pejoratywny wpływ na kreatywność ucznia. Jak podkreśla badacz, już sama obietnica profitów zewnętrznych działa negatywnie na motywację endogenną (wewnętrzną) i poziom twórczego myślenia.

Szczególnie podejście behawiorystyczne zakłada, że motywacja zewnętrzna, związana $\mathrm{z}$ wzmocnieniami pozytywnymi (nagrodami) oraz negatywnymi (karami) stanowi główny mechanizm wywołujący dane zachowanie (w tym przypadku zachowanie jest postrzegane jako instrumentalne, a nagrody i kary są głównym narzędziem zmiany zachowania. Niezwykle ciekawa praca Byrona i Khazanchiego (2012) rozstrzyga niejako spór dotyczący nagradzania uczniów. Jeden z typów nagród - nagrody związane ze stopniem kreatywności realizacji zadania - są istotnie pozytywnie związane $\mathrm{z}$ przyszłymi dokonaniami twórczymi badanych. Co ciekawe, nagrody za najlepsze wykonanie zadania lub związane z rywalizacją mają zaś negatywny związek z dokonaniami twórczymi. Lepper i in. (2005) zauważają, iż uczniowie zmotywowani zewnętrznie mają niższe osiągnięcia szkolne niż rówieśnicy z dominującą motywacją wewnętrzną. Obecnie jednak podkreśla się, że skutecznym czynnikiem w procesie dydaktycznym jest pochwała. Jest ona najskuteczniejszą formą motywacji zewnętrznej (wzmocnienia pozytywnego). Postuluje się obecnie, że system wzmocnień pozytywnych może dać trwałe efekty, natomiast wzmocnienia negatywne dają efekt czasowy (Reykowski 1970).

Często wydaje się, że skoro określone zagadnienia programowe są ujęte, to oznacza, że uczniowie muszą się ich nauczyć. Czy rzeczywiście tak jest? Z punktu widzenia funkcjonowania OUN takie założenie jest problematyczne. Wiedzy nie można przekazać - wbrew powszechnej opinii, zatem traktowanie uczniów jako odbiorców jest błędem i źródłem szkolnych niepowodzeń. Opierając się na wiedzy na temat funkcjonowania mózgu, można wyjaśnić, dlaczego system testowy, który w założeniu miał być czynnikiem motywującym (motywacja zewnętrzna), w wielu przypadkach przynosi efekt odwrotny - pejoratywny. Wiele wskazuje na to, że do powstawania szkolnych problemów przyczynia 
się zbyt uproszczona wizja przebiegu procesów uczenia się. Podkreślić należy tutaj, że uczenie się to aktywny proces nadawania znaczeń, który u każdego człowieka przebiega inaczej. Niezwykle ważne jest, jak podkreśla Brzezińska (2005), iż akceptacja odmienności uczniów, zrozumienie szybkości zmian na przestrzeni lat (wiadomo, że warunki życia się zmieniają) powoduje konieczność postrzegania relacji edukacyjnej jako obustronnej: nauczyciel-uczniowie, ale też uczniowie nauczyciel.

W literaturze przedmiotu dotyczącej podstawowych teorii uczenia się funkcjonują trzy podejścia: behawiorystyczne, poznawczo-procesualne, fenomenologiczno-humanistyczne. Oczywiście wszystkie te nurty to podejścia hipotetyczne - oparte na psychologicznych obserwacjach, często niepoparte jednak ścisłym biologicznym estymatorem lub w rzeczywistości nie mogące funkcjonować osobno - bez siebie (funkcjonują one wspólnie, bowiem każdy z tych nurtów tłumaczy niezwykle skomplikowane zjawisko, jakim jest uczenie się).

W ujęciu behawiorystycznym człowiek jako istota reaktywna, podlega oddziaływaniu bodźców, które wywołują określone reakcje. Wielokrotne powtarzanie prowadzi zaś do utrwalenia schematu: bodziec-reakcja. W tym rozumieniu oczywiście proces uczenia się odbywa się poprzez działanie i obserwację. Z biologicznego punktu widzenia podejście tłumaczy się, zgodnie z koncepcją Donalda Hebba, długotrwałym wzmocnieniem synaptycznym, które jest przede wszystkim związane z układem glutaminergicznym oraz eksternalizacją (uzewnętrznieniem błonowym) receptorów tego układu (Tsumoto 1992). Oczywiście niezwykle istotnym zagadnieniem jest tutaj także, opisywane przez Edwarda L. Thorndike’a (1911) prawo efektu, które wskazuje, iż jeśli połączenie między bodźcem a reakcją zostaje wzmocnione i wywołuje zadowolenie, związek ten zostanie zachowany, jeśli natomiast wywołuje emocje negatywne - wygaszony. Ogromną rolę w opisywanym zjawisku odgrywa układ nagrody, którego niedostateczne pobudzanie jest coraz częstszą egzemplifikacją niepoprawnie prowadzonego procesu nauczania.

Fantastyczną relację między uczeniem się a przyjemnością (zachwytem) opisał Gerald Huther (2016). Żywiołowe reakcje małych dzieci na wszystko, co budzi ich ciekawość są spowodowane i zarazem potęgują wzmożoną sekrecję neurotransmitterów i neuromodulatorów układu limbicznego. Stymulacja ta skutkuje oczywiście powstawaniem nowych połączeń synaptycznych.

Złożoność powiązań między procesami zapamiętywania/uczeniem się i radością/przyjemnością z nauki ilustruje Manfred Spitzer (2011) autor książki Jak uczy się mózg, pisząc: 
Gdy panowała moda na pokemony, a w telewizji można było oglądać kolejne serie filmów o tych stworach, dzieci zbierały karteczki z ich podobiznami, wykorzystywały je w grach i wymieniały się nimi. Przeprowadzono wtedy bardzo proste badanie. Kilkuletnim dzieciom najpierw pokazano obrazki z pokemonami i poproszono o podanie ich imion, a potem ilustracje zwierząt. Okazało się, że wszystkie potrafiły nazwać więcej pokemonów niż zwierząt.

Przykład ten pokazuje jak silny jest związek uczenia się z przeżywaniem emocjonalnym. Oczywiście należy tutaj zwrócić uwagę, iż niezwykle silne oddziaływanie ma tutaj motywacja endogenna dzieci, jednakże sam czas spędzany nad konkretnym zagadnieniem będzie wpływał i miał swoje konsekwencje w zdobytej wiedzy.

Z punktu widzenia teorii poznawczo-procesualnej uczenie się jest procesem podlegającym rozwojowi sekwencyjnemu (Piaget 1964). Oczywiście tak jest, potwierdzają to badania m.in. Rebecca Saxe (2003, 2004), która wskazała stadia rozwojowe, częściowo powtarzając za Piagetem, a przede wszystkim ukazała rolę kory przedczołowej (związanej m.in. z myśleniem abstrakcyjnym oraz postrzeganiem moralności) i jej dojrzewania jako nowego wyznacznika rozwoju dziecka. Teorie kognitywne podkreślają rolę asymilacji nowo przyswajanych doświadczeń do struktury doświadczeń już posiadanych, co oczywiście jest związane z swoistego rodzaju porównywaniem nowo pozyskanych informacji w strukturach układu limbicznego, takich jak hipokampy, czy ciała migdałowate, z informacjami już nabytymi (Vetulani 2006). Silnie związany z podejściem kognitywnym konstruktywizm przyjmuje założenie, że tzw. konstrukcja wiedzy w umyśle jednostki (uczącego się) może następować w różny sposób, tj. każdy uczący się dochodzi do nowej wiedzy w inny sposób. W obecnie obligatoryjnym sposobie myślenia pedagoga, odnajdziemy potrzebę aktywnego udziału uczącego się oraz nauczyciela zarówno w generowaniu sytuacji problemowych, jak i ich rozwiązywaniu. Zgodnie z nurtem fenomenologiczno-humanistycznym uczniowie postrzegani są jako indywidualności o zróżnicowanych potrzebach, ale też możliwościach. Proces uczenia się rozpatruje się holistycznie, podkreślając rolę interakcji między mentorem (nauczycielem) i uczniami oraz między samymi uczniami. Według tej teorii efekty uczenia się schodzą jednak na dalszy plan, wynosząc na piedestał sam proces uczenia się (Myszkowska-Litwa 2011). Uczniowie mają prawo wyboru oraz pewną swobodę, czego i jak się uczyć. Należy tutaj pamiętać, iż podchodząc do tego nurtu poważnie, nie można rozpatrywać go nie znając sekwencyjności rozwoju i nie dostosowywać progresu zakresu swobody i wyboru. Oczywiście przez to, że koncepcja ta podkreśla rolę również wykorzystania pamięci proceduralnej, automatyzmów ruchowych czy 
integracji sensorycznej jest ona kolejną cegiełką w tłumaczeniu całego procesu uczenia.

Powiązanie opisywanych nurtów, postrzeganych jako jeden koncept z rolą motywacji w procesie uczenia się pokazuje, że zarówno motywacja zewnętrzna (pozytywna-nagradzająca), jak i motywacja wewnętrzna (samoistna) wpływają na osiągnięcia szkolne.

\section{Zdolności a kompetencje szkolne}

Zdolności, zdaniem Włodzimierza Szewczuka (1983), to sprawnościowe atrybuty jednostki, decydujące o poziomie i jakości jej osiągnięć w wykonywaniu określonych działań. Według Pietrasińskiego natomiast (1976) są to różnice indywidualne, które sprawiają, że przy danym zasobie wiedzy i sprawności oraz w takich samych warunkach zewnętrznych i przy równej motywacji niektóre osoby uczą się szybciej nowych rzeczy niż pozostali. Wincenty Okoń (1996) uważa, że zdolność przejawia się w łatwości, szybkości i niezawodności potwierdzenia i przetwarzania informacji, w umiejętności podejmowania decyzji oraz w skutecznym, samodzielnym i twórczym działaniu.

Szewczuk wyróżnia pięć ogólnych zdolności: spostrzegawczość, inteligencja, wyuczalność, emotywność i zręczność. Działalność ludzka jest ukierunkowana na realizację określonych zadań, które wyznaczają jej treść. Tu pojawia się pojęcie zdolności specjalnych, zwanych też uzdolnieniami, które są „zespołem warunków wewnętrznych jednostki umożliwiających jej wykonywanie określonej, ukierunkowanej treściowo działalności” (Szewczuk 1998). Są one ściśle powiązane z określoną dziedziną, w której mogą się przejawiać. Przeprowadzone analizy wśród uczniów w Polsce oraz w Niemczech potwierdziły, jak wskazuje Sękowski (1998), iż zdolności silnie powiązane $\mathrm{z}$ poziomem inteligencji ogólnej sprzyjają znacznym osiągnięciom szkolnym w zakresie nauk ścisłych, humanistycznych oraz artystycznych. Już Jan Strelau wskazywał (Sękowski, Bilyakovska 2011), że zdolności i inteligencja mają najistotniejsze znaczenie dla kompetencji związanych z wykonywaniem konkretnych działań, czy czynności. Uczniowie, którzy osiągali dobre wyniki z matematyki, uzyskiwali wyższe wyniki $w$ testach badających zdolności operowania materiałem liczbowym. Uczniowie zaś o znacznych osiągnięciach humanistycznych, mieli wyższe wyniki w testach oceniających poziom zdolności operowania materiałem webralnym (Sękowski 1998). 
Zdolności człowieka mają dużą szansę zostać dostrzeżone i rozwijane w okresie szkolnym, kiedy dziecko ma wiele okazji do ich ukazania, i gdy znajdują się wokół niego osoby mające doświadczenie i umiejętności, aby dostrzec tkwiący w dziecku potencjał. Aby ten potencjał nie został zmarnowany, potrzebne jest podmiotowe podejście do ucznia, pozwalające na jego wszechstronny rozwój, w tym na rozwój jego zdolności.

Istnieje wiele podziałów dotyczących uczniów zdolnych. Według typologii autorstwa Josepha L. Frencha możemy wyróżnić uczniów uzdolnionych intelektualnie, uczniów zdolnych do nauki szkolnej, mających też ogólne lub kierunkowe uzdolnienia intelektualne, uczniów z ukrytymi talentami, które ujawniają się w specyficznych warunkach oraz uczniów o dużym potencjale twórczym z pewnym poziomem inteligencji (IQ powyżej 115) i rodzajem zdolności specjalnych (Szewczuk 1998).

Podobnego rozróżnienia dokonuje Danuta Nakoneczna (1980). Wyróżnia ona pięć grup uczniów zdolnych: (1) uczniowie o wysokich zdolnościach intelektualnych, którzy odznaczają się równie wysokimi osiągnięciami w zakresie większości przedmiotów szkolnych; (2) uczniowie o dość dużych uzdolnieniach intelektualnych, którzy osiągają wysokie wyniki w zakresie niektórych - wybranych przedmiotów kształcenia; (3) uczniowie, którzy nie są ponadprzeciętnie zdolni, a dobre wyniki w nauce zawdzięczają głównie własnej pracowitości oraz opiece ze strony środowiska społecznego; (4) uczniowie o dużych zdolnościach intelektualnych, którzy nie osiągają zadowalająco wysokich wyników w nauce; (5) uczniowie z ukrytymi talentami, które zostają ujawnione nie za pomocą testów, lecz na skutek działania silnych bodźców mobilizujących do pracy oraz w wyniku zapewnienia uczniom odpowiednich warunków do tworzenia.

Obecnie należy zwrócić uwagę, że dzieci zdolne powinny być traktowane jako osoby o specjalnych potrzebach edukacyjnych. Do potrzeb tych zaliczamy aspekty poznawcze, emocjonalne, społeczne, motywacyjne oraz potrzeby związane z rozwojem aktywności twórczej.

W sferze poznawczej uczniów zdolnych charakteryzuje m.in. ciekawość i aktywność poznawcza, dokładność, dociekliwość, umiejętność zadawania pytań, wielość zainteresowań, otwartość na to, co nowe, samodzielność w zdobywaniu wiedzy. W sferze emocjonalno-społecznej cechą ucznia zdolnego może być otwartość i wrażliwość na potrzeby innych osób, obowiązkowość, odpowiedzialność, skupienie się na własnych zadaniach kosztem ograniczenia aktywności społecznej, introwersja, krytyczne nastawienie do procesu edukacyjnego, wytrwałość, bezkompromisowość, preferowanie towarzystwa dorosłych. Jeśli 
chodzi o motywację, to uczeń zdolny kieruje się zazwyczaj motywacją wewnętrzną. Ponadto ma on żywą wyobraźnię, wytwarza oryginalne pomysły, dokonuje nietypowych skojarzeń i ma potrzebę ekspresji w różnych formach. Zdolne dzieci często przejawiają negatywne zachowania, które wynikają z ich nadwrażliwości psychomotorycznej, intelektualnej bądź emocjonalnej i również z tymi problemami wiąże się wiele specjalnych potrzeb tej grupy uczniów. Aby specjalne potrzeby edukacyjne ucznia zdolnego zostały zaspokojone, należy w pracy dydaktyczno-wychowawczej uwzględnić wszystkie jego cechy.

Obecnie w edukacji uczniów zdolnych wykorzystywane są różnorodne formy nauczania zindywidualizowanego. Należą do nich szkoły dla uczniów o szczególnych uzdolnieniach, klasy uczniów wyselekcjonowanych ze względu na zdolności i osiągnięcia grupy uczniów w klasie, którzy realizują poszerzone programy edukacyjne, wcześniejsze promocje prowadzące do przyspieszonego toku nauczania, nauczanie indywidualne w systemie jednoosobowej klasy oraz nauczanie zindywidualizowane $\mathrm{w}$ ramach wybranych przedmiotów związane z uzdolnieniami ucznia i jego zainteresowaniami (Dyrda 2012).

Zdecydowanie najbardziej kontrowersyjnym rozwiązaniem wydaje się nauczanie indywidualne - odbywa się ono poza naturalnym środowiskiem dziecka, bez udziału rówieśników. Należy pamiętać, iż stymulowana jest wyłącznie sfera intelektualna, nie rozwijając sfery społecznej i emocjonalnej. Korzystniejsze wydaje się zindywidualizowane nauczanie ucznia lub grupy uczniów w naturalnym środowisku szkolnym. W takich grupach można wprowadzać indywidualizację treści merytorycznych, czy indywidualizację metodyczną.

Sposobami wzbogacania treści kształcenia są m.in. przygotowywanie specjalnych programów dla uczniów zdolnych, różnicowanie planów i programów kształcenia (kursy obligatoryjne i fakultatywne). Warto zauważyć, iż indywidualizacja może dotyczyć także czasu przeznaczonego na wykonywania danego ćwiczenia oraz sposobu jego wykonania.

Tadeusz Lewowicki wskazuje też na szybsze opanowywanie materiału nauczania dzięki funkcjonowaniu klas „półrocznych” (semestralnych), wprowadzeniu „wydłużonego” roku szkolnego (wówczas w czasie roku szkolnego i wakacji uczeń realizuje program przeznaczony na dwa lata), podwójnej promocji oraz uczeniu się zgodnie $z$ indywidualnym tempem (Lewowicki 1980). Przyspieszanie podzielić można na „całościowe” oraz „częściowe”. O przyspieszaniu częściowym mówimy wówczas, gdy przyspieszenie procesu uczenia się uczniów zdolnych odbywa się tylko w zakresie niektórych zdolności kierunkowych. 
Natomiast o całościowym wówczas, gdy odbywa się ono w zakresie wszystkich, bądź większości zdolności ogólnych i kierunkowych (Lewowicki 1980).

Oczywiście, aby zapobiec koncentracji nauczyciela na uczniu zdolnym kosztem pozostałych lub odwrotnie, konieczne jest przygotowanie kadry pedagogicznej do pracy ze zróżnicowanym zespołem klasowym. Obecnie uważa się, iż w pracy z uczniem zdolnym należy a priori uwzględnić różne formy samokształcenia. Podkreśla się rolę pomocy nauczycielskiej w kompletowaniu materiałów i doborze odpowiedniej lektury do samokształcenia. Ważne jest również, aby nauczyciel zachęcał do śledzenia i uczestnictwa w życiu kulturalnym i społecznym. Należy zachęcać dzieci i młodzież do samodzielnej nauki oraz podtrzymywać wysoki poziom motywacji wewnętrznej, wskazując im przydatność wiedzy i przygotowując do właściwego posługiwania się wiedzą teoretyczną $\mathrm{w}$ różnych sytuacjach problemowych. Należy też zwrócić uwagę na rozwój twórczości, któremu sprzyja akceptowanie nietypowych, niestandardowych propozycji rozwiązań (Dyrda 2012; Gołębniak 2003).

\section{Podsumowanie}

Kompetencje szkolne uwarunkowane są zarówno czynnikami endogennymi, jak i egzogennymi. Nie sposób stwierdzić, który z czynników najsilniej wpływa na osiągnięcia szkolne. Bez wątpienia osoby o niższym IQ mogą na zasadzie kompensacji, poprzez motywację wewnętrzną czy zewnętrzną osiągać lepsze wyniki. Inteligencja, która bardzo często wiązana jest ze zdolnościami ogólnymi, determinuje pewien niepodważalny potencjał ucznia $\mathrm{w}$ procesie uczenia się. Szczególną w tej predyspozycji odgrywa intelekt wrodzony, który rozwijany jest przez cały okres adolescencji. Jednak, aby ten potencjał mógł być wykorzystany właściwie $\mathrm{w}$ procesie nauczania muszą być spełnione pewne warunki, włączając w to właściwą motywację, zgodnie z naturalnym funkcjonowaniem umysłu dziecka. Osobowość, która jest silnie zdeterminowana genetycznie i powiązana, jak podkreślono, z aktywnością dopaminergicznego szlaku nagrody, będzie warunkowała podejście nauczyciela. Wydaje się, iż obecnie powszechny system edukacji oparty o nagrody i kary, sprzyja rozwojowi osób ekstrawertycznych, ale nie introwertycznych. Potwierdził to niejako w swoich badaniach Colin D. Elliott (1972) sugerując, że ekstrawersja sprzyja osiągnięciom szkolnym na wczesnych etapach edukacji. Odmiennie jednak jest w okresie młodzieńczym, gdzie to introwersja może pomagać w odnoszeniu 
sukcesów. Niewątpliwie związane jest to z większą świadomością uczniów w wieku poniżej 12 lat, gdzie system nagród i kar przestaje być aż tak silnie eksponowany.

Analiza złożoności opisywanych czynników pokazuje, że praca pedagoga musi być stale obserwowana i w miarę potrzeb modyfikowana. Niezwykle ciekawym zagadnieniem jest pojęcie ucznia zdolnego i analiza pracy nauczyciela oraz ogólnie całego systemu oświaty w celu zapewnienia jak najlepszej opieki mentorskiej i pedagogicznej. Szereg badań, których fokusem jest analiza mózgowych korelat uczenia się pokazuje, że niezwykle istotnym aspektem jest kreatywność i że należy aktywizować uczniów, a także zapewniać im możliwość samorealizacji i swoistego rodzaju samokształcenia. System edukacyjny powinien być zorganizowany tak, aby wspierał rozwój cech indywidualnych. Cytując wspaniałą książkę Lucy M. Montgomery Ania z Avonlea: „W każdej istocie tkwią zarodki dobrego, trzeba tylko je umieć odnaleźć. Obowiązkiem nauczyciela jest odszukać je i rozwinąć" - zdanie to jest bez wątpienia kwintesencją pedagogiki.

\section{Bibliografia}

Addington A.M., Gornick M., Duckworth J., Sporn A., Gogtay N., Bobb A., Greenstein D., Lenane M., Gochman P., Baker N., Balkissoon R., Vakkalanka R.K., Weinberger D.R., Rapoport J.L., Straub R.E. 2005. GAD1 (2q31.1), which encodes glutamic acid decarboxylase (GAD67), is associated with childhood-onset schizophrenia and cortical gray matter volume loss, „Molecular Psychiatry”, nr 10, s. 581-588.

Aguilar-Alonso A. 1996. Personality and creativity, „Personality and Individual Differences”, nr 21.

Altink M.E., Rommelse N.N., Slaats-Willemse D.I., Vasquez A.A., Franke B., Buschgens C.J., Fliers E.A., Faraone SV., Sergeant J.A., Oosterlaan J., Buitelaar J.K. 2012. The dopamine receptor D4 7-repeat allele influences neurocognitive functioning, but this effect is moderated by age and ADHD status: an exploratory study, „The World Journal of Biological Psychiatry”, nr 13, s. 293-305.

Amabile T.M. 1983. The social psychology of creativity: A componential conceptualization, ,Journal of Personality and Social Psychology", nr 45 (2).

Amabile T.M. 1985. Motivation and creativity: Effects of motivational orientation on creative writers, ,Journal of Personality and Social Psychology”, $\mathrm{nr} 48$ (2).

Ashton M.C., Lee K., Son C. 2000. Honesty as the sixth factor of personality: correlation with machiavellianism, primary psychopathy, and social adroitness, „European Journal of Personality", nr 14, s. 359-368.

Ashton M.C., Lee K. 2001. A theoretical basis for the major dimensions of personality, „European Journal of Personality”, nr 15, s. 327-353. 
Barnett J.H., Scoriels L., Munafo M.R. 2008. Meta-analysis of the cognitive effects of the catechol-o-methyltransferase gene Val158/108Met polymorphism, „Biological Psychiatry”, nr 64, s. 137-144.

Becker P. 1999. Beyond the big five, „Personality and Individual Differences”, nr 26 (3), s. 511-530.

Benes F.M. 2001. The development of prefrontal cortex: The maturation of neurotransmitter systems and their interactions, „Handbook of Developmental Cognitive Neuroscience”, $\mathrm{nr} 2$, s. 79-92.

Benson M.A., Newey S.E., Martin-Rendon E., Hawkes R., Blake D.J. 2001. Dysbindin, a novel coiled-coil-containing protein that interacts with the dystrobrevins in muscle and brain, „The Journal of Biological Chemistry", nr 276, s. 24232-24241.

Blair C., Gamson D., Thorne S., Baker D. Rising mean IQ. 2005. Cognitive demand of mathematics education for young children, population exposure to formal schooling, and the neurobiology of the prefrontal cortex, „Intelligence”, $\mathrm{nr} 33$ (1), s. 93-106.

Blake J.D., Nawrotzki R., Loh N.Y., Górecki D., Davies K.E. 1998. $\beta$-dystrobrevin, a member of the dystrophin-related protein family, „Proceedings of the National Academy of Sciences” USA, nr 95, s. 241-246.

Bolton J.L., Marioni R.E., Deary I.J., Harris S.E., Stewart M.C., Murray G.D., Fowkes F.G., Price J.F. 2010. Association between polymorphism of the dopamine receptor D2 and catecholo-methyl transferase genes and cognitive function, „Behavior Genetics”, $\mathrm{nr}$ 40, s. 630-638.

Bouchard T.J., Lykken D.T., McGue M., Segal N.L., Tellegen A. 1990. Sources of human psychological differences: the Minnesota study of twins reared apart, „Science”, nr 250, s. 223-228.

Brown A.L., DeLoache J.S. 1978. Skills, plans, and self-regulation. Children's thinking: What develops, red. R. Siegler, Lawrence Erlbaum Associates, New Jersey, s. 3-35.

Brzezińska A. 2005. Jak przebiega rozwój człowieka, [w:] Psychologiczne portrety człowieka. Praktyczna psychologia rozwojowa, red. A.I. Brzezińska, Gdańskie Wydawnictwo Psychologiczne, s. 21-39.

Burdick K.E., Lencz T., Funke B., Finn C.T., Szeszko P.R., Kane J.M., Kucherlapati R., Malhotra A.K. 2006. Genetic variation in DTNBP1 influences general cognitive ability, „Human Molecular Genetics”, nr 15, s. 1563-1568.

Byron K., Khazanchi S. 2012. Rewards and Creative Performance: A Meta-Analytic Test of Theoretically Derived Hypotheses, „Psychological Bulletin”, nr 138 (4).

Chamorro-Premuzic T., Furnham A. 2008. Personality, intelligence and approaches to learning as predictors of academic performance, „Personality and Individual Differences”, nr 44 (7), s. 1596-1603.

Chirumbolo A., Leone L. 2010. Personality and politics: The role of the HEXACO model of personality in predicting ideology and voting, „Personality and Individual Differences”, nr 49 (1), s. $43-48$. 
Cools R., Calder A.J., Lawrence A.D., Clark L., Bullmore E., Robbins T.W. 2005. Individual differences in threat sensitivity predict serotonergic modulation of amygdala response to fearful faces, „Psychopharmacology”, nr 80, s. 670-679.

Cooper J.A., Sagar H.J. 1993. Encoding deficits in untreated Parkinson's disease, „Cortex”, nr 29, s. 251-265.

Costa P.T., McCrae R.R. 1992. Normal personality assessment in clinical practice: The NEO Personality Inventory, „Psychological Assessment”, nr 4 (1), s. 5.

Czelakowska D. 2007. Inteligencja i zdolności twórcze dzieci w poczq̨tkowym okresie edukacji: rozpoznawanie i kształcenie, Oficyna Wydawnicza Impuls, Kraków.

De Frias C.M., Annerbrink K., Westberg L., Eriksson E., Adolfsson R., Nilsson L.G. 2004. COMT gene polymorphism is associated with declarative memory in adulthood and old age, „Behavior Genetics", nr 34, s. 533-539.

De Fruyt F., Mervielde I. 1996. Personality and interests as predictors of educational streaming and achievement, „European Journal of Personality”, nr 10 (5).

De Raad B. 2009. Structural models of personality, [w:] The Cambridge Handbook of Personality Psychology, red. P.J. Corr, G. Matthews, Cambridge University Press, New York, s. 127-147.

Dewey J. 1938/1963. Experience and education, Collier Books, New York.

DeYoung C.G., Hirsh J.B., Shane M.S., Papademetris X., Rajeevan N., Gray J.R. 2010. Testing predictions from personality neuroscience: Brain structure and the big five, „Psychological Science", nr 21 (6), s. 820-828.

Dickinson D.B., Elvevag B. 2009. Genes, cognition and brain through a COMT lens, „Neuroscience”, nr 164, s. 72-87.

Diseth Å., Pallesen S., Brunborg G.S., Larsen S. 2010. Academic achievement among first semester undergraduate psychology students: the role of course experience, effort, motives and learning strategies, „Higher Education”, nr 59 (3), s. 335-352.

Dyrda B. 2012. Edukacyjne wspieranie rozwoju uczniów zdolnych, Wydawnictwo Akademickie ŻAK, Warszawa.

Egan M.F., Goldberg T.E., Kolachana B.S., Callicott J.H., Mazzanti C.M., Straub R.E., Goldman D., Weinberger D.R. 2001. Effect of COMT Val108/158 Met genotype on frontal lobe function and risk for schizophrenia, „Proceeding of the National Academy Sciences”, nr 98, s. 6917-6922.

Elliot C.D. 1972. Personality Factors and Scholastic Attainment, „British Journal of Educational Psychology", nr 42.

Eysenck H.J., Eysenck M.W. 1985. Personality and individual differences. A natural science approach, Plenum Press, New York.

Eysenck H.J.1995. Creativity as a product of intelligence and personality. In International handbook of personality and intelligence, Springer, Boston, MA, s. 231-247.

Feist G.J. 1998. A meta-analysis of personality in scientific and artistic creativity, „Personality and Social Psychology Review", nr 2.

Firkowska-Mankiewicz A. 2002. Intelligence and success in life, Wydawnictwo Filozofii i Socjologii PAN (IFiS), Warszawa. 
Fiske D.W. 1949. Consistency of the factorial structures of personality ratings from different sources, „The Journal of Abnormal and Social Psychology”, nr 44 (3), s. 329.

Flynn J.R. 1984. The mean IQ of Americans: Massive gains 1932 to 1978, „Psychological Bulletin”, nr 95 (1), s. 29.

Friedman H.S., Booth-Kewley S. 1987. The "disease-prone personality": A meta-analytic view of the construct, „American Psychologist”, nr 42 (6), s. 539.

Furnham A., Batey M., Booth T.W., Patel V., Lozinskaya D. 2011. Individual difference predictors of creativity in Art and Science students, , „Thinking Skills and Creativity”, $\mathrm{nr} 6$.

Furnham A., Chamorro-Premuzic T., Moutafi J. 2003. Personality and intelligence: Gender, the Big Five, psychometric and self-estimated intelligence, „International Journal of Selection and Assessment", nr 13 (1).

Furnham A., Medhurst S. 1995. Personality correlates of academic seminar behaviour: A study of four instruments, „Personality and Individual Differences”, nr 19 (2), s. 197-208.

Galton F. 1865. Hereditary talent and character, „Macmillan's magazine”, nr 12 (157-166), s. $318-327$.

Galton F. 1892. Finger prints, Macmillan and Company, New York.

Galton F. 1896. Hereditary genius: An inquiry into its laws and consequences (Vol. 27), Macmillan and Company, New York.

Goff M., Ackerman P.L. 1992. Personality-intelligence relations: Assessment of typical intellectual engagement, ,Journal of Educational Psychology”, nr 84 (4), s. 537.

Goldberg L.R. 1990. An alternative "description of personality”: the big-five factor structure, ,Journal of Personality and Social Psychology", nr 59 (6), s. 1216.

Goldberg L.R. 1981. Language and individual differences: The search for universals in personality lexicons, „Review of Personality and Social Psychology”, nr 2 (1), s. 141-165.

Goldman-Rakic P.S., Bourgeois J.P., Rakic P. 1997. Synaptic substrate of cognitive development: Life-span analysis of synaptogenesis in the prefrontal cortex of the nonhuman primate, „Development of the Prefrontal Cortex: Evolution, Neurobiology, and Behavior”, nr 27-47.

Gołębniak B.D. 2003. Szkoła wspierająca rozwój, [w:] Pedagogika. Podręcznik akademicki, t. 2, red. Z. Kwieciński, W. Śliwerski, Wydawnictwo Naukowe PWN, Warszawa.

Goleman D. 1999. La práctica de la inteligencia emocional, Editorial Kairós, Barcelona.

Gottfredson L.S. 1997. Why g matters: The complexity of everyday life, „Intelligence”, nr 24 (1), s. 79-132.

Gottfried A.E. 1985. Academic intrinsic motivation in elementary and junior high school students, ,Journal of Educational Psychology", nr 77 (6).

Gowan J.C. 1955. The underachieving gifted child-a problem for everyone, „Exceptional Children”, nr 21.

Gralewski J., Karwowski M. 2012. Creativity and school grades: A case from Poland, „Thinking Skills and Creativity", nr 7 (3).

Gray J.A. McNaughton N. 2000. The neuropsychology of anxiety: An enquiry into the functions of the septo-hippocampal system, Oxford University Press, New York. 
Greenspan S.I., Benderly B.L. 2000. Rozwój umysłu: emocjonalne podstawy inteligencji, Dom Wydawniczy Rebis, Poznań.

Hamer D., Copeland P. 1998. Living with our genes, „World And I”, nr 13, s. 274-277.

Harter S. 1981. A new self-report scale of intrinsic versus extrinsic orientation in the classroom: Motivational and informational components, „Developmental Psychology”, nr 17.

Hattie J. 2003. Teachers make a difference. What is the research evidence?, University of Auckland, Auckland.

Heaven P.C., Mak A., Barry J., Ciarrochi J. 2002. Personality and family influences on adolescent attitudes to school and self-rated academic performance, „Personality and Individual Differences", nr 32 (3), s. 453-462.

Hendriks A.A.J., Kuyper H., Lubbers M.J., Van der Werf M.P.C. 2011. Personality as a moderator of context effects on academic achievement, ,Journal of School Psychology”, nr 49.

Hennig J. 2004. Personality, serotonin, and noradrenaline, [w:] On the psychobiology of personality: Essays in honor of Marvin Zuckerman, red. R.M. Stelmack, Elsevier, New York.

Hoseinifar J., Siedkalan M.M., Zirak S.R., Nowrozi M., Shakerc A., Meamarc E., Ghaderid E. 2011. An investigation of the relation between creativity and five factors of personality in students, „Social and Behavioral Sciences”, nr 30.

Hughes D.J., Furnham A., Batey M. 2013. The structure and personality predictors of self-rated creativity, „Thinking Skills and Creativity”, nr 9.

Hüther G. 2016. Bedienungsanleitung für ein menschliches Gehirn, Vandenhoeck \& Ruprecht, Göttingen.

Hyde T.M., Lipska B.K., Ali T., Mathew S.V., Law A.J., Metitiri O.E., Straub R.E., Ye T., Colantuoni C., Herman M.M., Bigelow L.B., Weinberger D.R., Kleinman J.E. 2011. Expression of GABA signaling molecules KCC2, NKCC1, and GAD1 in cortical development and schizophrenia, ,Journal of Neuroscience”, nr 31, s. 11088-11095.

Izdebski P. 2007. The role of personality and temperamental factors in breast cancer: A 5-year prospective examination, „Polish Psychological Bulletin”, nr 4 (38), s. 198-205.

Karwowski M. 2006. Motywowanie uczniów do działań twórczych - między romantyzmem a behawioryzmem, „Ruch Pedagogiczny”, nr 3-4.

Karwowski M., Gralewski J. 2013. Threshold hypothesis: Fact or artifact?, „Thinking Skills and Creativity", nr 8, s. 25-33.

Kline P., Cooper C. 1986. Psychoticism and creativity, „The Journal of Genetic Psychology”, s. 147. Konarzewski K. 1996. Problemy i schematy. Pierwszy rok nauki szkolnej dziecka, Wydawnictwo Akademckie Żak, Warszawa.

Kossowska M., Nęcka E. 1994. Do it your own way: cognitive strategies, intelligence, and personality, „Personality and Individual Differences”, nr 1, s. 33-46.

Lachman H.M., Papolos D.F., Saito T., Yu Y.M., Szumlanski C.L., Weinshilboum R.M. 1996. Human catechol-o-methyltransferase pharmacogenetics: description of a functional polymorphism and its potential application to psychiatric disorders, „Pharmacogenetics”, nr 6, s. 243-250. 
Laidra K., Pullmann H., Allik J. 2007. Personality and intelligence as predictors of academic achievement: A cross-sectional study from elementary to secondary school, „Personality and Individual Differences", $\mathrm{nr} 42$.

Lepper M.R., Corpus H.J., lyengar S.S. 2005. Intrinsic and extrinsic motivational orientations in the classroom: Age differences and academic correlates, ,Journal of Educational Psychology”, nr 97 (2).

Leverenz J.B., Quinn J.F., Zabetian C., Zhang J., Montine K.S., Montine T.J. 2009. Cognitive impairment and dementia in patients with Parkinson disease, „Current Topics in Medicinal Chemistry", nr 9, s. 903-912.

Lewowicki T. 1980. Ksztatcenie uczniów zdolnych, Wydawnictwa Szkolne i Pedagogiczne, Warszawa, s. 53-54.

Luciano M., Wright M.J., Duffy D.L., Wainwright M.A., Zhu G., Evans D.M., Geffen G.M., Montgomery G.W., Martin N.G. 2006. Genome-wide scan of IQ finds significant linkage to a quantitative trait locus on 2q, „Behavior Genetics”, nr 36, s. 45-55.

Mayer J.D., Caruso D.R., Zigler E., Dreyden J.I. 1989. Intelligence and intelligence - related personality traits, „Intelligence”, nr 13, s. 119-133.

McCrae R.R., Costa Jr P.T., Martin T.A. 2005. The NEO-PI-3: A more readable revised NEO personality inventory, ,Journal of Personality Assessment”, nr 84 (3), s. 261-270.

McCrae R.R., Costa Jr P.T. 1999. A five-factor theory of personality, „Handbook of Personality: Theory and Research", nr 2, s. 139-153.

McCrae R.R., Costa Jr P.T. 1997. Personality trait structure as a human universal, „American Psychologist”, nr 52 (5), s. 509.

Merten T., Fischer I. 1999. Creativity, personality, and word association responses: Associative behavior in forty supposedly creative persons, „Personality and Individual Differences”, nr 27.

Mill J., Caspi A., Williams B.S., Craig I., Taylor A., Polo-Tomas M., Berridge C.W., Poulton R., Moffitt T.E. 2006. Prediction of heterogeneity in intelligence and adult prognosis by genetic polymorphisms in the dopamine system among children with attention-deficit/ hyperactivity disorder: evidence from 2 birth cohorts, „Archives of General Psychiatry”, nr 63, s. 462-469.

Myszkowska-Litwa M. 2011. Podejście humanistyczne $w$ działalności pedagogicznej, „Rocznik Komisji Nauk Pedagogicznych".

Nakoneczna D. 1980. Kształcenie wielostronne stymulujq̨ce rozwój uzdolnień, Wydawnictwa Szkolne i Pedagogiczne, Warszawa.

Netter P. 2004. Personality and hormones. On the psychobiology of personality: Essays in honor of Marvin Zuckerman, Elsevier, New York, s. 353-377.

Norman W.T. 1963. Toward an adequate taxonomy of personality attributes: Replicated factor structure in peer nomination personality ratings, „The Journal of Abnormal and Social Psychology”, nr 66 (6), s. 574.

O’Hara R., Miller E., Liao C.P., Way N., Lin X., Hallmayer J. 2006. COMT genotype, gender and cognition in community-dwelling, older adults, „Neuroscience Letters”, nr 409, s. 205-209. 
Oberle E., Schonert-Reichl K.A. 2013. Acceptance in the classroom is mediating the relationship between inhibitory control abilities and math grade, ,Journal of Applied Developmental Psychology", nr 34.

Okoń W. 1996. Nowy słownik pedagogiczny, Wydawnictwo Akademickie Żak,Warszawa.

Parkerson J.A., Schiller D.P., Lomax R.G., Walberg H.J. 1984. Exploring Causal Models of Educational Achievement, ,Journal of Educational Psychology”, nr 76 (4).

Piaget J. 1964. Cognitive development in children: Piaget development and learning, ,Journal of Research in Science Teaching", nr 2 (3), s. 176-186.

Pietrasiński Z. 1976. Zdolności, [w:] Psychologia, red. T. Tomaszewski, PWN, Warszawa.

Pintrich P., Zusho A. 2002. The development of academic self-regulation: The role of cognitive and motivational factors, [w:] Development of achievement motivation, red. A. Wigfield, J.S. Eccles, Academic Press, San Diego, CA.

Plomin R., McClearn G.E., Smith D.L., Skuder P., Vignetti S., Chorney M.J., Chorney K., Kasarda S., Thompson L.A., Detterman D.K., Petrill S.A., Daniels J., Owen M.J., McGuffin P. 1995. Allelic association between 100 DNA markers and high versus low IQ, „Intelligence”, nr 21, s. 31-48.

Plomin R., Turic D.M., Hill L., Turic D.E., Stephens M., Williams J., Owen M.J., O’Donovan M.C. 2004. A functional polymorphism in the succinate-semialdehyde dehydrogenase (aldehyde dehydrogenase 5 family, member A1) gene is associated with cognitive ability, „Molecular Psychiatry", nr 9, s. 582-586.

Poropat A.E. 2009. A meta-analysis of the five-factor model of personality and academic performance, „Psychological Bulletin”, nr 135 (2).

Pospiszyl K. 1992. Psychopatia, Wydawnictwo Naukowe PWN, Warszawa.

Renzulli J.S. 1986. The three-ring conception of giftedness: A developmental model for creative productivity, [w:] Conceptions of giftedness, red. R.J. Sternberg, J.E. Davidson, Cambridge University Press, New York.

Reykowski J. 1970. Natura ludzka a potrzeby, „Etyka”, nr 6, s. 31-49.

Reynolds A.J., Walberg H.J. 1991. A Structural Model of Science Achievement, ,Journal of Educational Psychology", nr 83 (1).

Roche S.H., McConkey K.M. 1990. Absorption: nature, assessment and correlates, ,Journal of Personality and Social Psychology”, nr 59, s. 91-101.

Saucier G. 2008. Measures of the personality factors found recurrently in human lexicons, [w:] The Sage Handbook of Personality Theory and Assessment, t. 2, red. G.J. Boyle, G. Matthews, D.H. Saklofske, SAGE Publication, Los Angeles-London-New Delhi-Singapore, s. 29-54.

Saxe R., Carey S., Kanwisher N. 2004. Understanding other minds: linking developmental psychology and functional neuroimaging, „Annual Review of Psychology”, nr 55, s. 87-124.

Saxe R., Kanwisher N. 2003. People thinking about thinking people: the role of the temporo-parietal junction in "theory of mind”, ,Neuroimage”, nr 19 (4), s. 1835-1842.

Schwab S.G., Knapp M., Mondabon S., Hallmayer J., Borrmann-Hassenbach M., Albus M., Lerer B., Rietschel M., Trixler M., Maier W., Wildenauer D.B. 2003. Support for association of schizophrenia with genetic variation in the 6p22.3 gene,' dysbindin, in sib-pair families 
with linkage and in an additional sample of triad families, „The American Journal of Human Genetics", nr 72, s. 185-190.

Sękowski A.E., Bilyakovska O. 2011. Zdolności człowieka jako wymiar psychologiczny, „Języki obce w szkole", nr 1, s. 18-24.

Sękowski A.E. 1998. Wybrane różnice indywidualne a osiagnnięcia uczniów zdolnych, „Przegląd Psychologiczny”, nr 41, s. 105-120.

Semendeferi K., Lu A., Schenker N., Damásio H. 2002. Humans and great apes share a large frontal cortex, „Nature neuroscience”, nr 5 (3), s. 272.

Soderqvist S., Bergman Nutley S., Peyrard-Janvid M., Matsson H., Humphreys K., Kere J., Klingberg T. 2012. Dopamine, working memory and training induced plasticity: implications for developmental research, „Developmental Psychology, $\mathrm{nr}$ 48, s. 836-843.

Spearman C. 1946. Theory of general factor, „British Journal of Psychology”, nr 36 (3), s. 117-131. Spitzer M. 2011. Jak uczy się mózg, tłum. M. Guzowska-Dąbrowska,Wydawnictwo Naukowe PWN, Warszawa.

Sternberg R.J., Davidson J.E. 1983. Insight in the gifted, „Educational Psychologist”, nr 18 (1), s. $51-57$.

Sternberg R.J. 1985. Implicit theories of intelligence, creativity, and wisdom, ,Journal of Personality and Social Psychology”, nr 49 (3), s. 607.

Strus W., Cieciuch J. 2014. Poza Wielkq Piq̨tkę - przegląd nowych modeli struktury osobowości, „Polskie Forum Psychologiczne”, nr 19 (1), s. 17-49.

Szewczuk W. 1983. Trudności myślenia i rozwijanie zdolności uczniów, Wydawnictwa Szkolne i Pedagogiczne, Warszawa.

Szewczuk W. 1998. Encyklopedia psychologii, Fundacja Innowacja, Warszawa.

Talbot K., Eidem W.L., Tinsley C.L., Benson M.A., Thompson E.W., Smith R.J., Hahn C.G., Siegel S.J., Trojanowski J.Q., Gur R.E., Blake D.J., Arnold S.E. 2004. Dysbindin-1 is reduced in intrinsic, glutamatergic terminals of the hippocampal formation in schizophrenia, "The Journal of Clinical Investigation”, nr 113, s. 1353-1363.

Taraszkiewicz M. 2014. Szukajq̨c dziury w całym - refleksje o uczeniu i nauczaniu, „Meritum”, nr 3 (34), s. 31-38.

Tellegen A., Atkinson G. 1974. Oppeness to absorbing and selfaltering experience ("absorbtion"): A trait related to hypnotic susceptibility, ,Journal of Abnormal Psychology”, nr 83, s. 286-277.

Terman L.M., Merrill M.A. 1937. Measuring intelligence, University of British Columbia, Vancouver.

Thorndike E.L 1911. Animal intelligence, Macmillan, New York.

Tsumoto T. 1992. Long-term potentiation and long-term depression in the neocortex, „Progress in Neurobiology", nr 39 (2), s. 209-228.

Tupes E.C., Christal R.E. 1992. Recurrent personality factors based on trait ratings, ,Journal of Personality", nr 60 (2), s. 225-251.

Vetulani J. 2006. Pamięć: Podstawy neurobiologiczne i możliwości wspomagania, „Farmakoterapia w Psychiatrii i Neurologii”, nr 22 (1), s. 7-18. 
Walker B., Jackson C.J. 2014. How the Five Factor Model and revised Reinforcement Sensitivity Theory predict divergent thinking, „Personality and Individual Differences”, nr 57.

Waltz J.A., Knowlton B.J., Holyoak K.J., Boone K.B., Mishkin F.S., de Menezes Santos M., Miller B.L. 1990. A system for relational reasoning in human prefrontal cortex, „Psychological Science", nr 10 (2), s. 119-125.

Wechsler D. 1949. Wechsler Intelligence Scale for Children, manuskrypt.

Weickert C.S., Straub R.E., McClintock B.W., Matsumoto M., Hashimoto R., Hyde T.M., Herman M.M., Weinberger D.R., Kleinman J.E. 2004. Human dysbindin (DTNBP1) gene expression in normal brain and in schizophrenic prefrontal cortex and midbrain, „Archives of General Psychiatry", nr 61, s. 544-555.

Wieczorkowska G., Siarkiewicz M. 2007. Inteligencja ucznia a wynik egzaminu, „Egzamin, Biuletyn Badawczy", CKE, s. 13.

Woody E., Claridge G. 1977. Psychoticism and thinking, „British Journal of Social and Clinical Psychology", s. 16.

Zhang J.P., Burdick K.E., Lencz T., Malhotra A.K. 2010. Meta-analysis of genetic variation in DTNBP1 and general cognitive ability, „Biological Psychiatry”, nr 68, s. 1126-1137. 